\title{
Pengaruh online dan offline reservations terhadap tingkat hunian kamar hotel jayakarta yogyakarta
}

\author{
Rr. Paulina Cristi Herlikano ${ }^{1)}$, Ni Putu Ratna Sari²), Agung Sri Sulistyawati ${ }^{3)}$
}

Program Studi Diploma IV Pariwisata, Fakultas Pariwisata, Universitas Udayana, Denpasar, Bali Universitas Udayana, J1. Dr. Goris Nomor 7 Denpasar, Bali 80232. Telp / Fax (0361) 223798,

E-mail : paulinaacristi@gmail.com

\begin{abstract}
Abstrak
Pemilihan pemesanan cenderung ditentukan oleh buying behaviour konsumen, melihat hal inip ela ku bisnis perhotelan memanfaatkan dalam hal pemasaran, baik sumber pemesanan online maupun offline unt uk meningkatkan tingkat hunian kamar. Penelitian yang berlokasidi The Ja yakarta Yogyakarta Hotel a nd Spa y ang terletak di Sleman, Yogyakarta ini bertujuan untuk mengetahui pengaruh online dan offline reservations baik secara simultan dan parsial terhadap tingkat hunian kamar, dan mengeta hui v a riabel y ang do minan mempengaruhi tingkat hunian kamar a ntara online dan offline reservation serta untuk mengetahui upaya yang dilakukan untuk meningkatkan tingkat hunian kamar diThe Jayakarata Yogyakarta Hotel and Spa. Penelitian ini merupakan penelitian deskriptif kuantitatif. Pengambilan data dalam penelitian ini dila kukan dengan teknik observasi, wa wancara, studi kepustakaan dan dokumentasi. Teknik a nalisis da ta men ggunakan uji validitas, ujirea bilita s, uji a sumsi klasik, a nalisis korelasi berganda, a nalisis regresi berga nda, pengujian Ftest, pengujian t, koefisien deteminasi. Hasil penelitianinimenunjukan bahwa secara simultan terdapat penga ruh yang positif dan signifikan antara online reservations dan offline reservations te rhadap tin gkat hunian kamar di The Jayakarta Yogyakarta Hotel and Spa. Halini ditunjukkan oleh nilai $F_{\text {hitung }}(3196,788)>$ $F_{\text {tabel }}(3,28)$. Pada uji $t$ online reservations $t_{\text {hitung }}(10,272)>t_{\text {tabel }}(2,032)$, uji $\mathrm{T}$ offline reservations $t_{\text {hitung }}$ $(14.563)>t_{\text {tabel }}(2,032)$ dankoefisien determinasi 99,5 persen. Variabely ang lebih dominan mempengaruhi tingkat hunian kamar secara parsial kedua variabel berpengaruh secara signifikan adalah variabel offline reservations. Hal ini dibuktikan dari uji determinasi dengan hasil yang didapatkan 86,2 persen tingkat hunian ka mar dipengaruhi oleh offline reservations, serta 75,6 persen tingkat hunian kamar dipengaruhi oleh on line reservation. Upaya yang dilakukan untuk meningkatkan variabel y ang tidak domin an dengan mengikuti seminar yang diadakan oleh komunitas-kominitas E-commerce dan online trav el a gent, m emperhatik an review ma syarakat, memberikan informasi terbaru kepada masyarakat terkait dengan informasi hotel maupun promosi yang diadakan.
\end{abstract}

Kata kunci : Online Reservation, Offline Reservations, Tingkat Hunian Kamar, The Jayakarta Yogyakarta

\begin{abstract}
Selection of reservations tends to be determined by consumer buying behavior, thus hoteliers take advantage for marketing about online and offline booking sources to increase room occupancy. This Research located at The Jayakarta Yogya karta Hotel and Spa, Yogyakarta aims to determine the influence of online and offline reservations both simultaneously and partially on room occupancy, and find out which the dominant variables affect room occupancy rates between online and offline reservations and to find out the efforts made to increase roomoccupancy at The Jayakarata Yogyakarta Hoteland Spa. This research is descriptive quantitative. Retrieval of data on this studywas carried out by observations, interviewed, literature studies, anddocumentations. Data analysis techniques are using validity test, reliability test, classic assumption test, multiple correlation analysis, multiple regression analysis, $F$-test, $t$-test, coefficient of determination, effective contribution and relative contribution. The results of this research in dicate that simultaneously there are positive and significantbetween online and offline reservations on the room occupancy at The Jayakarta Yogyakarta Hotel and Spa. This is indicated by the value of Fcount (3196,788)> Ftable (3.28). In the t-test of online reservations has $t_{\text {count }}(10.272)>t_{\text {table }}(2.032)$, for offline reservations t test has $t_{\text {count }}(14.563)>t_{\text {table }}(2.032)$ and the coefficient of determination is 99.5 percent. The dominant va riable partially influences room occupancy and the affecting significantly variables is offline reservations variable. This is evidenced from the determination test with the results obtained 86.2 percent of the roo $m$ occup ancy rate is influenced by offline reservations, and 75.6 percent of the room occupancy rate is influenced byonline reservation. The Efforts are made to increase the non-dominant variabels by attending seminars held by the E-commerce communities and online travel agents, give attention to guest reviews, update the information for public related about hotel information.
\end{abstract}

Keywords : Online Reservation, Offline Reservations, Room Occupancy, The Jayakarta Yogyakarta 


\section{PENDAHULUAN}

Menurut WHO (World Health Organization) industri pariwisata merupakan salah satu industri terbesar di dunia. Industri pariwisata dapat menyerap tenaga kerja dalam jumlah yang besar, mampu meningkatkan pendapatan dan perekonomian serta dapat memberikan kontribusi yang besar pada suatu negara. Hal inil yang mendorong banyak negara tertarik untuk mengembangkan pariwisata sebagai salah satu sektor pembangunan, terutama bagi negara yang sedang berkembang termasuk Indonesia.

Kota Yogyakarta merupakan salah satu kota terbesar di Indonesia. Yogyakarta atau lebih sering disebut Jogja, mendapat berbagai macam julukan seperti Kota Pelajar, Kota Gudeg, Kota Perjuangan, Kota Pariwisata, maupun Kota Budaya. Jogja telah menyediakan berbagai atraksi yang dapat dinikmati oleh pelancong yang berkunjung. Banyak hal menarik yang ditawarkan di jogja seperti tempat pariwisatanya, budaya dari masyarakatnya maupun dari masakan tradisionalnya. Karena hal tersebutlah yang menjadikan jogja memiliki daya tarik tersendiri bagi wisatawan yang ingin berkunjung. Hal ini terbukti dari jumlah wisatawan yang berkunjung ke jogja mengalami kenaikan setiap tahunnya. Berikut merupakan tabel Pertumbuhan Kunjungan Wisatawan ke DIY tahun 2014-2018

Tabel 1.Pertumbuhan Kunjungan Wisatawan DIY tahun 2014-2018

\begin{tabular}{cccccc}
\hline No & Tahun & $\begin{array}{c}\text { Wisatawan } \\
\text { Mancanegara }\end{array}$ & Pertumbuhan(\%) & $\begin{array}{c}\text { Wisatawan } \\
\text { Nusantara }\end{array}$ & Pertumbuhan(\%) \\
\hline 1 & 2014 & 254.213 & - & 3.091 .967 & - \\
2 & 2015 & 308.485 & 21,32 & 3.813 .720 & 23,34 \\
3 & 2016 & 355.313 & 15,18 & 4.194 .261 & 9,98 \\
4 & 2017 & 397.951 & 12,00 & 4.831 .347 & 15,19 \\
5 & 2018 & 416.372 & 4,63 & 5.272 .719 & 9,14 \\
\hline
\end{tabular}

Sumber: Statistik Kepariwisataan (2020)

Dari data kunjungan wisatawan tersebut dapat dilihat bahwa jumlah wisatawan yang berkunjung ke Daerah Istimewa Yogyakarta mengalami kenaikan setiap tahunnya dari wisatawan mancarnegara maupun wisatawan nusantara. Oleh karena itu tidak sedikit dibangun hotel sebagai tempat akomodasi bagi wisatawan yang berkunjung.

Hotel merupakan salah satu perusahaan yang bergerak dalam bidang jasa akomodasi atau penginapan. Secara umum hotel adalah suatu bentuk bangunan, lambang, perusahaan atau badan usaha akomodasi yang menyediakan pelayanan jasa penginapan, penyedia makanan dan minuman serta fasilitas jasa lainnya dimana semua pelayanan itu diperuntukkan bagi masyarakat umum. Berikut merupakan perkembangan hotel berbintang dan non berbintang di Yogyakarta.

Tabel 2. Pekembangan Hotel Berbintang dan Non Berbintang di Kawasan Yogyakarta ta hun 2014 2018

\begin{tabular}{ccccc}
\hline Tahun & $\begin{array}{c}\text { Hotel } \\
\text { Berbintang }\end{array}$ & $\begin{array}{c}\text { Pertumbuhan } \\
(\boldsymbol{\%})\end{array}$ & $\begin{array}{c}\text { Hotel Non } \\
\text { Berbintang }\end{array}$ & Pertumbuhan(\%) \\
\hline 2014 & 43 & - & 356 & - \\
2015 & 57 & 32,5 & 362 & 1,7 \\
2016 & 62 & 8,7 & 358 & $-1,1$ \\
2017 & 82 & 32,2 & 356 & $-0,6$ \\
2018 & 90 & 9,7 & 490 & 37,6 \\
\hline
\end{tabular}

Sumber: Badan Pusat Statistik Yogyakarta (2020)

Salah satu hotel yang terkenal di daerah Jogja adalah The Jayakarta Yogyakarta Hotel. Perkembangan persaingan bisnis di Indonesia adalah salah satu fenomena yang sangat menarik untuk diteliti, terlebih dengan adanya globalisasi dalam bidang ekonomi yang semakin membuka peluang pengusaha asing untuk turut berkompetisi dalam menjaring konsumen lokal. Dampak globalisasi menyebabkan industri jasa yang terdiri dari berb a gai macam industri seperti industri telekomunikasi, transportasi, perban kan, dan perhotelan berkembang dengan cepat (Zeithaml \& Bit dalam Sulastiyono, 2011:1). 
Di era globalisasi sekarang ini teknologi kian berkembang untuk mempermudah masyarakat berkomunikasi. Salah satu kemajuan teknologi oleh bidang perhotelan dimanfaatkan untuk pemesanan kamar hotel yang dapat dilakukan melalui pemesanan online maupun offline. Oleh karena itu, system pemasaran hotel mejadi hal yang sangat menentukan bagi kelangsungan dan keberlanjutan hotel dalam meneruskan usaha jasanya. Dalam hal ini The Jayakarta Yogyakarta Hotel juga menggunakan kedua reservasi online dan offline tersebut.

Tabel 3. Market Segment di Hotel The Jayakarta Yogyakarta

\begin{tabular}{l|c}
\hline \multicolumn{1}{c|}{ Market Segment } \\
\hline \multirow{3}{*}{ Offline } & Individual/Walk in \\
& Travelagent FIT \\
Travelagent GIT & Coorporate \\
& Government \\
& Airline \\
\hline \multirow{2}{*}{ Online } & Hotel Website \\
& Tra veloka.com \\
& Agoda Company Pte.Ltd. \\
& Booking.Com \\
& Pegipegi.Com \\
& Tiket.Com \\
& Fastbooking \\
& Expedia Tt \\
& Klikhotel.Com \\
& Trip.Com \\
& Hoteltravel \\
& Membership \\
\hline
\end{tabular}

Sumber: HotelThe Jayakarta Yogyakarta (2020)

Dari data tersebut dapat dilihat bahwa market segment dari hotel the Jayakarta Yogyakarta memiliki sumber-sumber reservasi dari berbagai sumber mulai dari walk-in, travel agen FIT dan GIT, coorporat, government, corporate office, airline dan membership. Sumbersumber reservasi terbut termasuk dalam online dan offline reservastions. Baik online maupun offline merupakan hal yang penting dalam pemasaran hotel tersebut sehingga menyebabkan kostumer memilih reservasi yang diinginkan.

Menurut Payne dalam Sulastiyono (2011:8) pemasaran jasa yaitu proses mempersepsikan, menstimulasi, memahami, dan memenuhi kebutuhan pasar sasaran yang secara khusus dipilih dengan menyalurkan sumber-sumber sebuah organisasi untuk memenuhi kebutuhan tersebut. Baik reservasi online maupun offline merupakan hal yang penting bagi costumer dalam memilih hotel yang diinginkan.

Tujuan dari penelitian ini yaitu Untuk mengetahui pengaruh online dan offline reservations baik secara simultan dan parsial terhadap tingkat hunian kamar di Hotel The Jayakarta Yogyakarta Hotel and Spa Untuk mengetahui variabel mana yang dominan mempengaruhi tingkat hunian kamar di Hotel The Jayakarta Yogyakarta Hotel and Spa, serta untuk mengetahui upaya yang dilakukan hotel untuk meningkatkan tingkat hunian kamar Hotel The Jayakarta Yogyakarta Hotel and Spa. 


\section{METODE PENELITIAN}

Devinisi Operasional Variabel berfungsi untuk memperjelas batasan- batasan penelitian serta menjelaskan variabel-variabel yang digunakan dalam penelitian sehingga ruang lingkup permasalahan penelitian dapat ditentukan dan dilihat dengan jelas.

1) Online Reservations

Online reservations adalah pemesanan kamar yang masuk melalui media intern et atau online melalui perusahaan online travel agent yang telah bekerja sama dengan Hotel the Jayakarta Yogyakarta, Membership dan dinyatakan sebagai $x_{1}$ yang dihitung selama 36 bulan pada periode Januari 2017 sampai Desember 2019, variabel ini din y atakan dalam satuan (kamar).

2) Offline Reservations

Offline reservations adalah pemesanan kamar yang masuk atau dilakukan tan pa melalui online tetapi melalui telepon, surat, faksimile dan telegram, biro - biro perjalanan dan usaha penerbangan. Offline reservation disini dinyatakan sebagai $\mathrm{x}_{2}$ yang dihitung selama 36 bulan pada periode Januari 2017 sampai Desember 2019, variabel ini dinyatakan dalam satuan (kamar).

3) Tingkat Hunian Kamar

Dalam penelitian ini tingkat hunian kamar dinyatakan sebagai Y. Tingkat hunian kamar yang dimaksud diperoleh Hotel The Jayakarta Yogyakarta selama 36 bulan periode Januari 2017 sampai Desember 2019, variabel ini dinyatakan dalam satuan (persen).

Jenis Data dalam penelitian ini adalah data kualitatif dan data kuantitatif. Sumber data yang digunakan adalah data primer dan data sekunder. Teknik pengumpulan datayang digunakan adalah dengan cara observasi, wawancara, studi kepustakaan dan dokumentasi. Dalam penelitian ini teknik penentuan sampelnya menggunakan data distribusi online dan offline reservations, dan tingkat hunian kamar selama 36 bulan pada periode Januari 2017 sampai Desember 2019.

Tabel 4. Distribusi Online Reservations, Offline Reservations dan Tingkat Hunian Kamar di The Jayakarta Yogyakarta Hoteland Spa periode Januari 2017 sampai Desember 2019

\begin{tabular}{|c|c|c|c|c|}
\hline Tahun & Bulan & $\begin{array}{c}\text { Reservations } \\
\text { Online (X1) } \\
\text { (Room Night) }\end{array}$ & $\begin{array}{c}\text { Reservations Offline } \\
\text { (X2) } \\
\text { (Room Night) }\end{array}$ & $\begin{array}{c}\text { Tingkat Hunian } \\
\operatorname{Kamar}(\mathbf{Y}) \\
(\%)\end{array}$ \\
\hline \multirow{11}{*}{2017} & Ja nuari & 495 & 1426 & 49,64 \\
\hline & Februari & 372 & 1310 & 43,46 \\
\hline & Maret & 314 & 1168 & 38,29 \\
\hline & April & 564 & 1534 & 54,21 \\
\hline & Mei & 539 & 1628 & 55,99 \\
\hline & Juni & 475 & 1438 & 49,43 \\
\hline & Juli & 656 & 1746 & 60,07 \\
\hline & Agustus & 452 & 1640 & 54,06 \\
\hline & September & 522 & 1677 & 54,99 \\
\hline & Oktober & 617 & 1459 & 53,64 \\
\hline & November & 462 & 1383 & 46,14 \\
\hline
\end{tabular}




\begin{tabular}{|c|c|c|c|c|}
\hline & Desember & 1042 & 1962 & 77,62 \\
\hline \multirow{12}{*}{2018} & Januari & 536 & 1123 & 42,87 \\
\hline & Februari & 789 & 1580 & 61,21 \\
\hline & Maret & 726 & 1350 & 53,64 \\
\hline & April & 595 & 1481 & 53,64 \\
\hline & Mei & 506 & 1201 & 44,11 \\
\hline & Juni & 989 & 1699 & 69,46 \\
\hline & Juli & 440 & 1067 & 38,94 \\
\hline & Agustus & 469 & 1331 & 46,51 \\
\hline & September & 644 & 1422 & 53,67 \\
\hline & Oktober & 451 & 1098 & 40,03 \\
\hline & November & 587 & 1401 & 51,37 \\
\hline & Desember & 690 & 1481 & 56,1 \\
\hline \multirow{12}{*}{2019} & Ja nuari & 577 & 1281 & 48,04 \\
\hline & Februari & 454 & 1018 & 38,11 \\
\hline & Maret & 504 & 1012 & 38,06 \\
\hline & April & 574 & 1276 & 47,8 \\
\hline & Mei & 685 & 1522 & 57,03 \\
\hline & Juni & 723 & 1321 & 52,07 \\
\hline & Juli & 541 & 1201 & 45,01 \\
\hline & Agustus & 703 & 1562 & 58,53 \\
\hline & September & 661 & 1469 & 55,04 \\
\hline & Oktober & 546 & 1154 & 45,5 \\
\hline & November & 623 & 1258 & 47,88 \\
\hline & Desember & 724 & 1563 & 59,97 \\
\hline
\end{tabular}

Sumber: Da ta Reservation The Jayakarta Yogyakarta Hotel and Spa (2020)

Teknik analisis data yang digunakan pada penelitian ini adalah uji valididas, uji reliabilitas, uji asumsi klasik, analisis regresi berganda, korelasi berganda, uji T, uji F, koefisien determinasi, sumbangan efektif dan sumbangan relatif.

Uji validitas menyatakan bahwa instrumen yang digunakan untuk mend apatkan data dalam penelitian dapat digunakan atau tidak. Menurut Supranto (1997:121) instrumen dapat dikatakan valid jika dapat mengukur apa yang seharusnya diukur atau mengukur ap a yang diinginkan dengan tepat. Nilai koefisien korelasi Pearson atau tabel Pearson $\left(\mathrm{r}_{\mathrm{tabel}}\right)$ pada taraf signifikansi $\alpha$ (biasanya dipilih 0,05 ) dan $n=$ banyaknya data yang sesuai dengan kriteria uji :

1) Instrumen valid, jika $r_{\text {hitung }} \geq r_{\text {tabel }}$ 
2) Instrumen tidak valid, jika $r_{\text {hitung }}<r_{\text {tabel }}$

Uji reliabilitas menurut Agus (2008:354) dilakukan untuk mengetahui seberapa jauh hasil pengukuran tetap konsisten apabila dilakukan pengukuran dua kali atau lebih terhadap gejala yang sama dengan menggunakan alat pengukur sama. Menurut Wiratna Sujarweni (2014:193) menjelaskan bahwa uji reliabilitas memiliki dasar pengambilan keputusan sebagai berikut :

1. Jika nilai Cronbach's Alpha $>0,06$ maka data tersebut dinyatakan reliabel atau konsisten.

2. Jika nilai Cronbach's Alpha $<0,06$ maka data tersebut dinyatakan tidak reliabel atau konsisten.

Uji Asumsi Klasik dalam penelitin ini terbagi menjadi 4 yaitu uji normalitas, autokorelasi multikolinieritas dan heterokedastisitas. Uji normalitas bertujuan untuk mengetahui apakah dalam model regresi variabel dependen dan variabel independen mempunyai kontribusi atau tidak (Ghozali 2012:160). Uji normalitas dilakukan dengan uji Kolmogonov-Smirnov Test, dengan kriteria uji :

1. Jika nilai probability Asymp. Sig (2-tailed) $<0,05$ maka distribusi adalah tidak normal.

2. Jika nilai probability Asymp. Sig (2-tailed) > 0,05 maka distribusi normal

Uji autokorelasi adalah untuk menguji apakah model regresi ada kolerasi antara kesalahan pengganggu pada periode-t dengan kesalahan pengganggu pada periode $\mathrm{t}-1$. Jika terjadi korelasi, maka dinamakan ada masalah autokorelasi.

Uji autokorelasi dapat dilakukan dengan Uji Durbin-Watson (DW-test) atau d statistik terhadap variabel pengganggu (disturbance error), yaitu dengan membandingkan nilai durbin Watson hitung (d) dengan nilai durbin Watson tabel, yaitu batas atas (du) dan batas bawah (dl). Kriteria pengujian tersebut yaitu sebagai berikut :

1. Jika $0<\mathrm{d}<\mathrm{dl}$, maka terjadi autokorelasi positif.

2. Jika $\mathrm{dl}<\mathrm{d}<\mathrm{du}$, maka tidak ada kepastian terjadi autokorelasi atau tidak.

3. Jika d-dl $<\mathrm{d}<4$, maka terjadi autokorelasi negative.

4. Jika 4-du $<\mathrm{d}<4$-dl, maka tidak ada kepastian terjadi autokorelasi atau tidak.

5. Jika du $<\mathrm{d}<4$-du, maka tidak terjadi autokorelasi positif atau negative.

Uji multikolinieritas dilakukan untuk menguji apakah pada model regresi ditemukan adanya korelasi antar variabel bebas. Untuk menguji multikoliniearitas dengan cara melihat nilai VIF dan Tolerance masing-masing variabel independen, Jika nilai Tolerance $>0,10$ dan nilai VIF < 10 maka dapat disumpulkan tidak ada multikoliniearitas (Purnomo, 2016:121).

Uji Heteroskedastisitas dilakukan untuk menguji apakah dalam model regresi terjadi ketidaksamaan variance dari residual satu pengamatan ke pengamatan yang lain. Uji heterokedastisitas pada penelitian ini menggunakan uji Glejser dengan kiteria uji ini yaitu jika nilai signifikansi hasil > 0,05 maka tidak mengalami heterokedastisitas (Purnomo, 2016:125).

Analisis ini digunakan untuk mengetahui tingkat atau derajat hubungan secara serempak antara online dan offline reservations sebagai variabel bebas dan tingkat hunian kamar hotel sebagai variabel terikat. $\mathrm{R}$ adalah korelasi berganda yaitu korelasi antara variabel bebas dengan variabel terikat (Purnomo, 2016:154).

Untuk mengetahui kuat lemahnya tingkat atau derajat hubungan koefisien korelasi menggunakan pedoman Supranto (Febriantara, 2012) 
1. $r=0,85-0,99$; hubungan sangat erat atau kuat

2. $r=0,70-0,84$; hubungan erat atau kuat

3. $r=0,50-0,69$; hubungan sedang

4. $r=0,30-0,49$; hubungan rendah

5. $r=0,20-0,29$; hubungan sangat rendah atau lamah

6. $r=0,01-0,19$; hubungan diabaikan

Analisis Regresi Berganda menurut Djarwanto dan Subagyo (Febriantara, 2012 digunakan untuk mengukur pengaruh dari online dan offline reservations sebagai (variabel bebas) terhadap tingkat hunian kamar hotel sebagai (variabel terikat) secara bersama-sama.

\section{Persamaan}

$y=\alpha+\beta_{1} x_{1}+\beta_{2} x_{2}$

$$
\alpha=y-\beta_{1} x_{1}-\beta_{2} x_{2}
$$

$\beta_{1}=\frac{\left(\sum x_{2}^{2}\right)\left(\sum x_{1} y\right)-\left(\sum x_{1} x_{2}\right)\left(\sum x_{2} y\right)}{\left(\sum x_{1}^{2}\right)\left(\sum x_{2}^{2}\right)-\left(\sum x_{1} x_{2}\right)^{2}}$

$\beta_{2}=\frac{\left(\sum x_{1}^{2}\right)\left(\sum x_{2} y\right)-\left(\sum x_{1} x_{2}\right)\left(\sum x_{1} y\right)}{\left(\sum x_{1}^{2}\right)\left(\sum x_{2}^{2}\right)-\left(\sum x_{1} x_{2}\right)^{2}}$

Keterangan :

$\mathrm{y} \quad=$ Tingkat Hunian Kamar (Variabel Terikat)

$\boldsymbol{x}_{\mathbf{1}}=$ Online reservations (variabel bebas)

$x_{2}=$ Offline reservations (variabel bebas)

$\boldsymbol{\alpha} \quad=$ Bilangan konstanta

$\boldsymbol{\beta}_{1} \boldsymbol{\beta}_{2}=$ Koefisien Regresi Linier Berganda

Kegunaan uji $\mathrm{F}$ untuk menguji pengaruh online dan offline reservations secara bersama-sama terhadap tingkat hunian kamar dengan level of significant (LOS) $=5$ persen 0,05 dan derajat kebebasan (df1) untuk pembilang (jumlah variabel-1) dan derajat kebebasan (df2) untuk penyebut (jumlah sampel-jumlah variabel). Jika nilai-nilai yang diperoleh lebih besar dari Ftabel, maka dapat diambil kesimpulan bahwa online dan offline reservations secara bersama-sama berpengaruh secara signifikan terhadap tingkat hunian kamar (Purnomo, 2016:169).

Langkah-langkah uji $\mathrm{F}$ atau uji simultan adalah:

1) Ho : diduga online reservations dan offline reservations secara bersama-sama tidak berpengaruh terhadap tingkat hunian kamar. 
Ha : diduga online reservations dan offline reservations secara bersama-sama berpengaruh terhadap tingkat hunian kamar.

2) Menentukan nilai F hitung dan nilai Signifikansi melalui program SPSS

3) Menentukan Ftabel pada tingkat signifikansi 0,05

$\mathrm{F}_{\text {tabel }}=\frac{d f(n 1)}{d f(n 2)}=\frac{\text { (jumlah variabel-1) }}{\text { (jumlah sampel-jumlah variabel) }}=\frac{3-1}{36-3}=3,28$ (lihat pada lampiran)

4) Kriteria Pengujian

1) Berdasarkan nilai Signifikansi (Sig)

Jika nilai Sig > 0,05 maka Ho diterima

Jika nilai Sig. $<0,05$ maka Ho ditolak

b. Berdasarkan perbandingan $\mathrm{F}$ hitung dan $\mathrm{F}$ tabel

Apabila $F_{\text {hitung }} \leq \mathrm{F}_{\text {tabel }}$ maka Ho diterima

Apabila $F_{\text {hitung }} \geq \mathrm{F}_{\text {tabel }}$ maka Ho ditolak

5) Pengambilan kesimpulan

a. Berdasarkan nilai Signifikansi

Apabila nilai Sig. > 0,05, maka online dan offline reservations tidak berpengaruh terhadap tingkat hunian kamar

Apabila nilai Sig $<0,05$, maka online dan offline reservations berpengaruh terhadap tingkat hunian kamar

b. Berdasarkan perbandingan $\mathrm{F}$ tabel dan $\mathrm{F}$ hitung

Apabila $F_{\text {hitung }}<\mathrm{F}_{\text {tabel }}$ maka tidak ada pengaruh antara online dan offline reservations terhadap tingkat hunian kamar secara simultan.

Apabila $F_{\text {hitung }}>F_{\text {tabel }}$ maka ada pengaruh antara online dan offline reservations terhadap tingkat hunian kamar secara simultan.

Uji t digunakan untuk mengetahui apakah variabel-variabel independen (online reservations dan offline reservtaions) secara parsial berpengaruh nyata atau tidak terhadap variabel dependen (tingkat hunian kamar). Pengujian menggunakan tingkat signifikansi 0,05 dengan 2 sisi (Purnomo, 2016:157).

Langkah-langkah uji T adalah:

Perumusan Hipotesis

1) Ho ; Diduga variabel online dan offline reservations tidak berpengaruh yang signifikan terhadap variabel tingkat hunian kamar.

Ha : Diduga variabel online dan offline reservations berpengaruh yang signifikan terhadap variabel tingkat hunian kamar.

2) Menentukan $t_{\text {hitung }}$ dan nilai Signifikansi melalui program SPSS

3) Menentukan $t_{\text {tabel }}$

$t_{\text {tabel }}$ dapat diketahui melalui tabel statistik pada tingkat signifikansi 0,05 dengan 2 sisi dengan

derajat kebebasan $\mathrm{df}=$ jumlah sampel $(36)-2=34$

$\mathrm{t}_{\text {tabel }}=2,032$ (lihat pada lampiran)

4) Penentuan Kriteria Penerimaan dan Penolakan.

a. Berdasarkan nilai Signifikansi

Apabila nilai Sig. > 0,05, maka Ho diterima

Apabila nilai Sig. > 0,05, maka Ho ditolak

2) Berdasarkan perbandingan $T$ tabel dan $T$ hitung

Apabila $t_{\text {hitung }} \leq \mathrm{t}_{\text {tabel, }}$ maka $\mathrm{H}_{\mathrm{O}}$ diterima

Apabila $t_{\text {hitung }}>t_{\text {tabel, }}$ maka Ho ditolak

5) Penarikan Kesimpulan

a. Berdasarkan nilai Signifikansi

Apabila Sig. $>0,000$ maka $\mathrm{H}_{\mathrm{o}}$ diterima, yang berarti tidak ada pengaruh

Apabila Sig. $<0,000$ maka $\mathrm{H}_{\mathrm{o}}$ ditolak, yang berarti adanya pengaruh yang signifikan

b. Berdasarkan perbandingan $t_{\text {hitung }}$ dan $t_{\text {tabel }}$ 
Apabila $\mathrm{t}_{\text {hitung }}<\mathrm{t}_{\text {tabel, }}$ maka $\mathrm{H}_{\mathrm{o}}$ diterima, yang berarti tidak ada pengaruh

Apabila $t_{\text {hitung }}>t_{\text {tabel, }}$ maka $\mathrm{H}_{\mathrm{o}}$ ditolak, yang berarti adanya pengaruh yang signifikan

Koefisien determinasi digunakan untuk mengetahui seberapa besar hubungan dari beberapa variabel dalam pengertian yang lebih jelas (Santoso, 2008:280). Analisis korelasi berganda dapat dilanjutkan dengan menghitung koefisien determinasi, dengan cara menguadratkan koefisien yang ditemukan. Pengertian ini sering digunakan untuk mengetahui seberapa pengaruh variabel $\mathrm{x}$ terhadap variabel y, dan sisanya ditentukan oleh faktor lain.

$D=R^{2} x 100 \%$

Keterangan :

$\mathrm{D}=$ Determinasi

$\mathrm{R}=$ Koefisien korelasi

\section{HASIL DAN PEMBAHASAN}

3.1 Pengaruh Online dan Offline reservations Terhadap Tingkat Hunian Kamar di The Jayakarta Yogyakarta Hotel and Spa

Berdasarkan pada rumusan masalah yang terdapat pada pendahuluan, untuk mengetahui pengaruh online dan offline reservations terhadap tingkat hunian kamar di The Jayakarta Yogyakarta Hotel and Spa baik secara simultan maupun parsial dan mengetahui seberapa besar pengaruh terdahap tingkat hunian kamar. Maka dilakukan pengumpulan data terhadap distribusi sumber sumber reservasi kamar baik secara online maupun offline reservaions sejak Januari 2017 sampai Desember 2019 yang ada di Tabel 2. Data tersebut kemudian di satndarisasi menggunakan z-score menggunakan software SPSS versi 25 kemudian dianalisis sebagai berikut.

Uji Validitas

Uji validitas ini dilakukan dengan tujuan untuk mengetahui data yang digunakan valid atau tidak, atau dengan kata lain data dalam penelitian dapat digunakan atau tidak.

Kriteria uji :

Nilai koefisien korelasi Pearson / tabel Pearson $\left(\mathrm{r}_{\text {tabel }}\right)$ pada taraf signifikansi $\alpha$ (biasanya dipilih 0,05 ) dan $n=$ banyaknya data yang sesuai.

1) Jika $r_{\text {hitung }} \geq r_{\text {tabel, }}$, maka instrumen valid,

2) Jika $r_{\text {hitung }}<r_{\text {tabel, }}$, maka nstrumen tidak valid

Tabel 5. Uji Validitas

\begin{tabular}{ccccc}
\hline & \multicolumn{3}{c}{ Correlations } \\
& $\begin{array}{c}\text { Zscore: Online } \\
\text { Reservation }\end{array}$ & $\begin{array}{c}\text { Zscore: Offline } \\
\text { Reservation }\end{array}$ & $\begin{array}{c}\text { Zscore: Tingkat } \\
\text { Hunian Kamar }\end{array}$ \\
\hline $\begin{array}{c}\text { Zscore: } \\
\text { Online } \\
\text { Reservation }\end{array}$ & $\begin{array}{c}\text { Pearson } \\
\text { Correlation }\end{array}$ & 1 & $.632^{* *}$ & $.870^{* *}$ \\
& Sig. (2-tailed) & $\mathrm{N}$ & .000 & .000 \\
\hline $\begin{array}{c}\text { Zscore: } \\
\text { Offline }\end{array}$ & Pearson & $.632^{* *}$ & 36 & 36 \\
\hline Coservation & Sig. (2-tailed) & .000 & 1 & $.928^{* *}$ \\
& & & & .000
\end{tabular}




\begin{tabular}{lcccc} 
& $\mathrm{N}$ & 36 & 36 & 36 \\
\hline $\begin{array}{l}\text { Zscore: } \\
\text { Tingkat }\end{array}$ & Pearson & $.870^{* *}$ & $.928^{* *}$ & 1 \\
Hunian & Correlation & & & \\
Kamar & Sig. (2-tailed) & .000 & .000 & 36 \\
& $\mathrm{~N}$ & 36 & 36 & \\
\hline
\end{tabular}

Correlation is significant at the 0.01 level(2-tailed).

Sumber: Da ta Primer yang Diolah (2020)

Data menunjukkan pada online reservations $r_{\text {hitung }}(0,87)>r_{\text {tabel }}(0,33)$ maka intrument online reservations dinyatakan valid. Pada offline reservations $\mathrm{r}_{\text {hitung }}(0,928)>$ $\mathrm{r}_{\text {tabel }}(0,33)$ maka intrument offline reservations dinyatakan valid.

Uji reliabilitas ini digunakan untuk mengetahui seberapa jauh hasil pengukuran tetap konsisten apabila dilakukan pengukuran dua kali atau lebih terhadap gejala yang sama dengan menggunakan alat pengukur sama.

Kriteria uji :

1) Jika nilai Cronbach's Alpha $>0,60$ maka data tersebut dinyatakan reliabel atau konsisten.

2) Jika nilai Cronbach's Alpha $<0,60$ maka data tersebut dinyatakan tidak reliabel atau konsisten.

Tabel 6. Uji Reliabilitas

\begin{tabular}{cc}
\multicolumn{2}{c}{ Reliability Statistics } \\
\hline $\begin{array}{c}\text { Cronbach's } \\
\text { Alpha }\end{array}$ & N of Items \\
\hline .928 & 3 \\
\hline
\end{tabular}

$\overline{\text { Sumber: Da ta Primeryang Diolah }}(2020)$

Dari data yang ada dapat dimiliki nilai Cronbach's Alpha sebesar 0,928. Maka ketiga variabel tersebut dinyatakan reliabel atau konsisten karena nilai Cronbach's Alpha $(0,928)>0,60$.

Uji asumsi klasik digunakan sebelum analisis linier berganda. Uji asumsi klasik ini dibagi menjadi empat yaitu Uji normalitas, Uji Autokorelasi, Uji multikolinieritas, Uji heteroskedastisitas.

Uji normalitas bertujuan untuk mengetahui apakah residual model regresi yang diteliti berdistribusi normal atau tidak. Model regresi yang baik yaitu data distriusi normal atau mendekati normal. Uji normalitas dilakukan dengan uji Kolmogorov-Smirnov Test.

Kriteria Uji :

1) Jika nilai probabilitas Asymp. Sig. (2-tailed) $<0,05$ maka distribusi adalah tidak normal

2) Jika nilai probabilitas Asymp. Sig. (2-tailed) $>0,05$ maka distribusi adalah normal

Tabel 7.Uji Normalitas

\begin{tabular}{ll|ccc}
\hline \multicolumn{4}{c}{ One-Sample Kolmogorov-SmirnovTest } \\
\hline & & $\begin{array}{c}\text { Zscore: Online } \\
\text { Reservation }\end{array}$ & $\begin{array}{c}\text { Zscore: Offline } \\
\text { Reservation }\end{array}$ & $\begin{array}{c}\text { Zscore: Tingkat } \\
\text { Hunian Kamar }\end{array}$ \\
\hline $\mathrm{N}$ & 36 & 36 & 36 \\
Normal & Mean & .0000000 & .0000000 & .0000000 \\
Parameters ${ }^{\mathrm{a} b}$ & Std. & 1.00000000 & 1.00000000 & 1.00000000 \\
& Deviation & & & \\
Most Extreme & Absolute & .103 & .062 & .090 \\
Differences & Positive & .100 & .062 & .090 \\
& Negative & -.103 & -.048 & -.085 \\
\cline { 3 - 5 } & & &
\end{tabular}


Test Statistic

Asymp.Sig.(2-tailed)

Sumber: Da ta Primer yang Diolah (2020)

Dapat dilihat bahwa nilai Asymp. Sig. (2-tailed) pada $\left(X_{1}=0,200, X_{2}=200, Y_{1}=0,200\right)$

$>0,05$. Sehingga dapat dikatakan bahwa data berdistribusi normal atau memenuhi syarat uji normalitas dan dapat digunakan untuk analisis lebih lanjut.

Uji autokorelasi bertujuan untuk mengetahui model regresi ada kolerasi antara kesalahan pengganggu pada periode-t dengan kesalahan pengganggu pada periode $\mathrm{t}-1$.

Kriteria uji :

a. $\quad$ Jika $0<\mathrm{d}<\mathrm{d}$ l, maka terjadi autokorelasi positif.

b. Jika dl $<\mathrm{d}<\mathrm{du}$, maka tidak ada kepastian terjadi autokorelasi atau tidak.

c. Jika d-dl $<\mathrm{d}<4$, maka terjadi autokorelasi negative.

d. Jika 4-du $<$ d $<4$-dl, maka tidak ada kepastian terjadi autokorelasi atau tidak.

e. Jika du $<\mathrm{d}<4$-du, maka tidak terjadi autokorelasi positif atau negative.

Tabel 8. Uji Autokorelasi

Model Summary ${ }^{\mathbf{b}}$

\begin{tabular}{cccc}
\hline Model & Adjusted R Square & Std.Error of the Estimate & Durbin-Watson \\
\hline 1 & .995 & .07379793 & 2.531
\end{tabular}

a. Predictors: (Constant), Zscore: Offline Reservation,Zscore: Online Reservation

b. Dependent Variable:Zscore: TingkatHunian Kamar

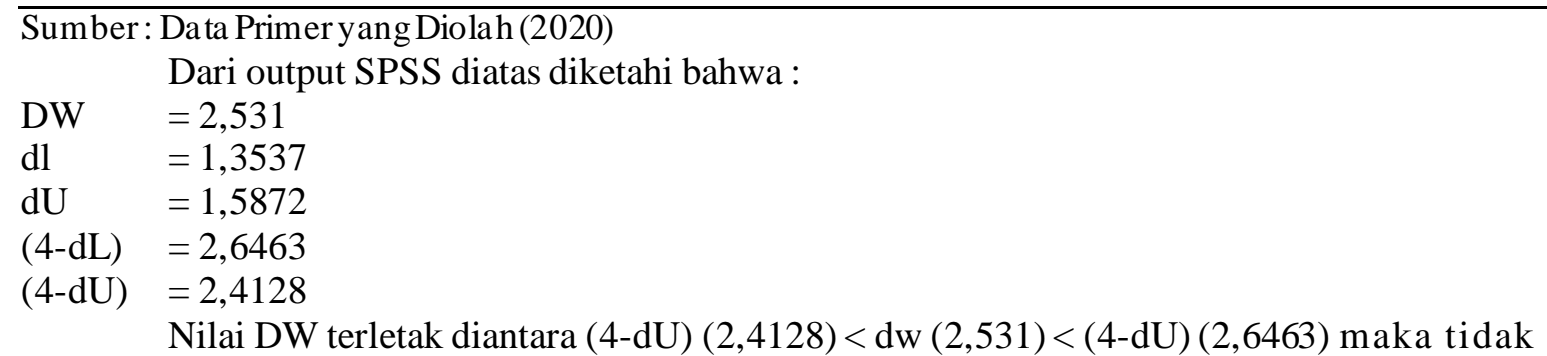
ada kepastian terjadi autokorelasi atau tidak.

Uji multikolinieritas digunakan untuk menguji apakah pada model regresi ditemukan adanya korelasi antar variabel bebas.

Kriteria Uji :

1) Jika nilai Tolerance $>0,10$ dan nilai $\mathrm{VIF}<10$, maka dapat disimpulkan tidak ada multikolinieritas antar variabel independen pada model regresi

2) Jika nilai Tolerance $<0,10$ dan nilai VIF $>10$, maka dapat disimpulkan ada multikolinieritas antar variabel independen pada model regresi

Tabel 9. Uji Mutikolinieritas

\begin{tabular}{ccc}
\hline & \multicolumn{2}{c}{ Coefficients $^{\mathbf{a}}$} \\
\cline { 2 - 3 } (Constant) & \multicolumn{2}{c}{ Collinearity Statistics } \\
\cline { 2 - 3 } Zscore: Online Reservation & & Tolarance \\
Zscore: Offline Reservation & .600 & 1.667 \\
& .600 & 1.667 \\
\hline a. Dependent Variable: Zscore: TingkatHunian Kamar &
\end{tabular}

Sumber: Da ta Primer yang Diolah (2020)

Nilai toleran dari online reservations dan offline reservations memiliki nilai yang sama yaitu 0,600 dan nilai VIF dari online reservations dan offline reservations juga memiliki nilai yang sama yaitu 1,667. Maka dapat diketahui bahwa nilai Tolerance $(0,600)>0,10$ dan nilai VIF 
$(1,667)<10$. Sehingga dapat disimpulkan tidak ada multikoliniearitas antar variabel independen pada model regresi. Uji heterokedastisitas digunakan untuk menguji apakah dalam sebuah model regresi terjadi ketidaksamaan varians dari residual antara satu pengamatan ke pengamatan yang lain.

Kriteria Uji :

1) Jika signifikansi hasil korelasi lebih kecil $(<)$ dari 0,05 $(5 \%)$ maka persamaan regresi tersebut mengandung heteroskedastisitas

2) Jika signifikansi hasil korelasi lebih besar (>) dari 0,05 (5\%) maka persamaan regresi tersebut tidak mengalami heteroskedastisitas atau homoskedastisitas. Tabel 10. Uji Heteroskedastisitas

\begin{tabular}{|c|c|c|c|c|c|c|}
\hline \multicolumn{7}{|c|}{ Coefficients $^{\mathbf{a}}$} \\
\hline & \multirow[t]{2}{*}{ Model } & \multicolumn{2}{|c|}{$\begin{array}{l}\text { Unstandardized } \\
\text { Coefficients }\end{array}$} & \multirow{2}{*}{$\begin{array}{c}\text { Standardized } \\
\text { Coefficients } \\
\text { Beta }\end{array}$} & \multirow[t]{2}{*}{$\mathrm{T}$} & \multirow[t]{2}{*}{ Sig. } \\
\hline & & $\mathrm{B}$ & Std.Error & & & \\
\hline \multirow{3}{*}{1} & (Constant) & .046 & .009 & & 5.163 & .000 \\
\hline & $\begin{array}{l}\text { Zscore: Online } \\
\text { Reservation }\end{array}$ & -.014 & .012 & -.266 & -1.219 & .231 \\
\hline & $\begin{array}{l}\text { Zscore: Offline } \\
\text { Reservation }\end{array}$ & .016 & .012 & 291 & 1.333 & .192 \\
\hline
\end{tabular}

a. Dependent Variable: RES2

Sumber: Da ta Primer yang Diolah (2020)

Variabel online reservations (X1) memiliki nilai signifikansi sebesar 0,231 dan untuk variabel offline reservations (X2) memiliki nilai signifikansi sebesar 0,192 dimana dari kedua nilai tersebut lebih besar (>) dari 0,05. Sehingga dalam penelitian ini dapat dikatakan tidak terjadi heterokedastisitas.

\subsection{Pengaruh Online Reservations dan Offline Reservations Terhadap Tingkat Hunian Kamar di The Jayakarta Yogyakarta Hotel and Spa}

Untuk mengetahui keeratan hubungan antara lebih dari satu variabel bebas X1 (online reservations) dan $\mathrm{X} 2$ (offline reservations) terhadap variabel terikat $\mathrm{Y}$ (tingkat hunian kamar) dapat menggunakan analisis berikut :

1. Analisis Korelasi Berganda

Hal tersebut diatur dengan satu nilai yang disebut koefisien korelasi berganda. Halam hal ini untuk mengetahui kuat lemahnya tingkat atau derajat hubungan koefisien korelasi menggunakan pedoman Untuk mengetahui kuat lemahnya tingkat atau derajat hubungan koefisien korelasi menggunakan pedoman Supranto (Febriantara, 2012)

1. $r=0,85-0,99$; hubungan sangat erat atau kuat

2. $r=0,70-0,84$; hubungan erat atau kuat

3. $r=0,50-0,69$; hubungan sedang

4. $r=0,30-0,49$; hubungan rendah

5. $r=0,20-0,29$; hubungan sangat rendah atau lamah

6. $r=0,01-0,19$; hubungan diabaikan 
Berdasarkan perhitungan analisis SPSS versi 25 dapat dilihat bahwa diperoleh persamaan jenis reservasi sebagai mana terlihat dibawah ini : Tabel 11. Korelasi Berganda

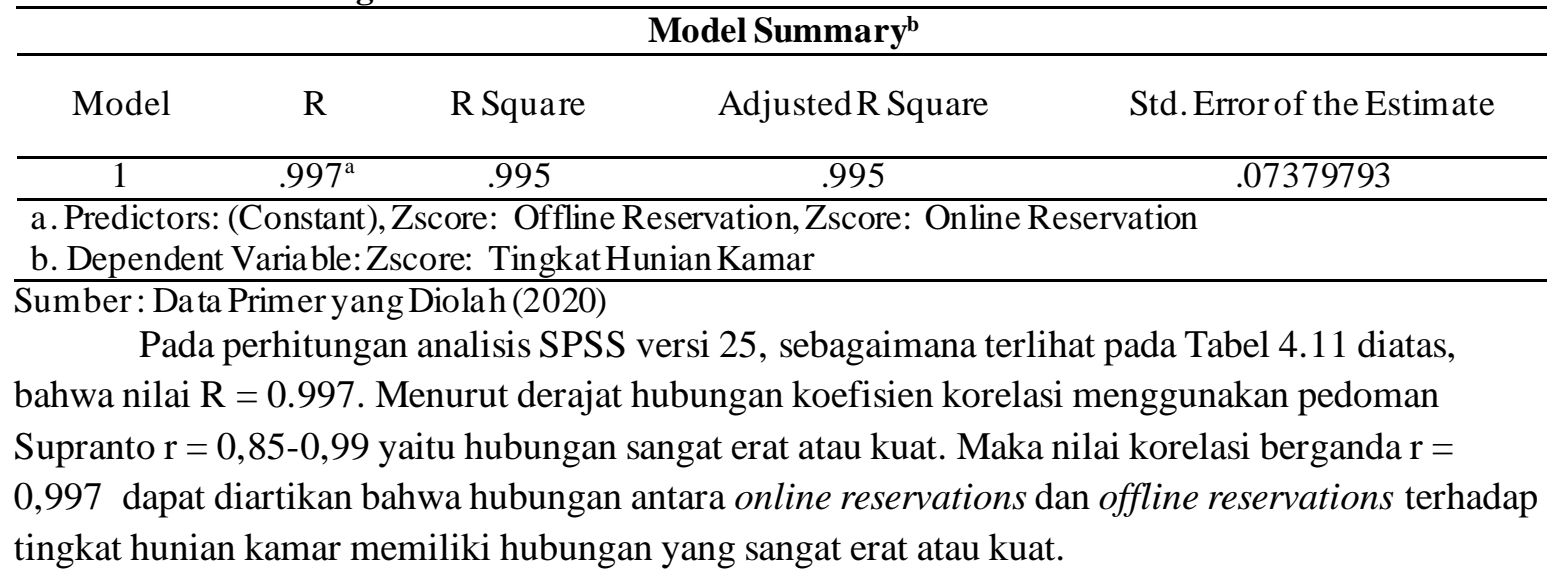

2. Analisis Regresi Berganda

Tabel 12. Regresi Berganda

\begin{tabular}{|c|c|c|c|c|c|c|}
\hline \multicolumn{7}{|c|}{ Coefficients $^{\mathbf{a}}$} \\
\hline & \multirow[t]{2}{*}{ Model } & \multicolumn{2}{|c|}{ Unstandardized Coefficients } & $\begin{array}{l}\text { Standardized } \\
\text { Coefficients }\end{array}$ & \multirow[t]{2}{*}{$\mathrm{T}$} & \multirow[t]{2}{*}{ Sig. } \\
\hline & & $\mathrm{B}$ & Std. Error & Beta & & \\
\hline \multirow{3}{*}{1} & (Constant) & $-1.892 \mathrm{E}-16$ & .012 & & .000 & 1.000 \\
\hline & $\begin{array}{l}\text { Zscore: Online } \\
\text { Reservation }\end{array}$ & .471 & .016 & .471 & 29.238 & .000 \\
\hline & $\begin{array}{l}\text { Zscore: Offline } \\
\text { Reservation }\end{array}$ & .631 & .016 & .631 & 39.155 & .000 \\
\hline
\end{tabular}

a.Dependent Variable: Zscore: Tingkat Hunian Ka mar

Sumber: Da ta Primer yang Diolah (2020)

Dari hasil perhitungan diatas diperoleh persamaan regresi sebagai berikut :

$\mathrm{y}=-1,892+0,471 \mathrm{x}_{1}+0,631 \mathrm{x}_{2}$

$\mathrm{y}=$ Tingkat Hunian Kamar

$\mathrm{x}_{1}=$ Online reservations

$\mathrm{x}_{2}=$ Offline reservations

Persamaan diatas memiliki arti sebagai berikut :

a. Nilai konstanta atau intercept $\alpha=-1,892$ berarti jika The Jayakarta Yogyakarta Hotel and Spa tidak mendapatkan pemesanan kamar melalui online dan offline reservations maka tingkat hunian kamar yaitu -1,892 persen.

b. Nilai $\mathrm{x}_{1}$ memiliki arti apabila terjadi kenaikan pemesanan kamar melalui pemesanan online sebanyak 1 kamar dan pemesanan kamar melalui online konstan, maka tingk at hunian kamar menjadi meningkat sebesar 0,471 persen.

c. Nilai $\mathrm{x}_{2}$, memiliki arti apabila kenaikan pemesanan kamar melalui pemesanan offline sebanyak satu kamar dan pemesanan kamar melalui online konstan, maka tingkat hunian kamar menjadi meningkat sebesar 0,631 persen.

Berdasarkan tabel data menunjukkan Sig untuk online reservations dan offline reservations sama-sama menunjukkan nilai sebesar $0,000(\mathrm{p}<0,05)$ maka variabel online reservations dan offline reservations berpengaruh signifikan terhadap tingkat hunian kamar.

Untuk mengetahui pengaruh online reservations dan offline reservations terhadap tingkat hunian kamar dapat diuji dengan Uji F dengan level significant 5 persen atau 0,05, perumusan hipotesis tersebut sebagai berikut (Purnomo : 169) :

Rumus F tabel : 
df 1 (pembilang) $=$ jumlah variabel $-1=3-1=2$

df 2 (penyebut) = jumlah sampel - jumlah variabel $=36-3=33$

$\mathrm{F}_{\text {tabel }}=3,28$

\section{Kriteria Uji :}

1) Berdasarkan nilai Signifikansi (Sig)

3) Jika nilai Sig. $<0,05$ maka variabel $X 1$ dan $X 2$ berpengaruh terhadap $Y$

4) Jika nilai Sig > 0,05 maka variabel $X 1$ dan $X 2$ tidak berpengaruh terhadap $Y$

2) Berdasarkan perbandingan nilai $F$ hitung dengan $F$ tabel

a. $\quad F_{\text {hitung }} \leq \mathrm{F}_{\text {tabel, }}$ berarti tidak ada pengaruh antara $\mathrm{X} 1$ dan $\mathrm{X} 2$ terhadap $\mathrm{Y}$

b. $\quad F_{\text {hitung }} \geq F_{\text {tabel, }}$, berarti ada pengaruh antara $X 1$ dan $X 2$ terhadap $Y$

Tabel 13. Uji F Test Online dan Offline Reservations

\begin{tabular}{|c|c|c|c|c|c|c|}
\hline \multicolumn{7}{|c|}{ ANOVA $^{\mathrm{a}}$} \\
\hline & Model & $\begin{array}{c}\text { Sum of } \\
\text { Squares }\end{array}$ & Df & Mean Square & $\mathrm{F}$ & Sig. \\
\hline \multirow{3}{*}{1} & Regression & 34.820 & 2 & 17.410 & 3196.788 & $.000^{\mathrm{b}}$ \\
\hline & Residual & .180 & 33 & .005 & & \\
\hline & Total & 35.000 & 35 & & & \\
\hline
\end{tabular}

a. Dependent Variable: Zscore: Tingkat Hunian Ka mar

b. Predictors: (Constant), Zscore: Offline Reservation, Zscore: Online Reservation

Sumber: Da ta Primeryang Diolah(2020)

Dari tabel diatas menunjukkan nilai Sig. yaitu sebesar 0,000. Karena nilai 0,000 < 0,05 , maka berdasarkan kriteria uji nilai signifikansi dapat disimpulkan variabel online reservations dan offline reservations secara simultan berpengaruh terhadap tingkat hunian kamar.

Uji $\mathrm{F}$ test online dan offline reservations diatas bahwa nilai $\mathrm{F}_{\text {hitung }}$ yaitu 3196,788. Sehingga didapat $F_{\text {hitung }}>F_{\text {tabel }}$ atau $F_{\text {hitung }}(3196,788)>F_{\text {tabel }}(3,28)$. Hal ini berarti antara online reservations dan offline reservations secara bersama-sama atau simultan berpengaruh secara nyata dan signifikan terhadap tingkat hunian kamar di The Jay akarta Yogyakarta Hotel and Spa.

Penentuan daerah penerimaan dan penolakan dalam hipotesis ini dapat dilihat pada Gambar 1 dibawah

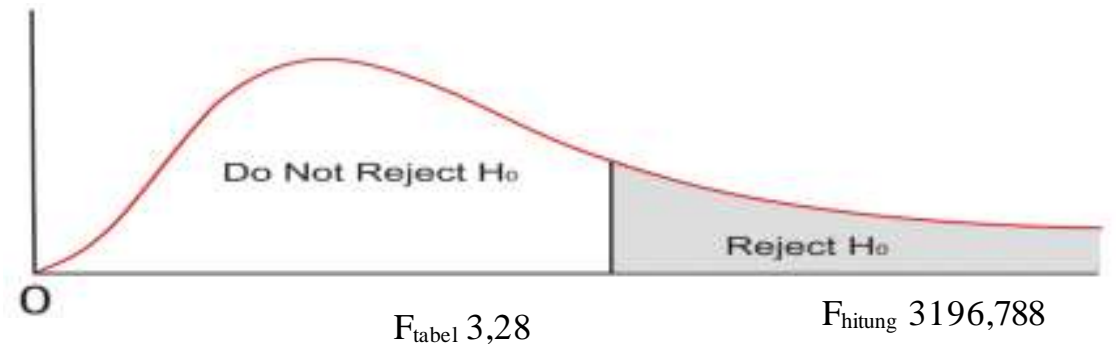

4. Uji t

Gambar 1 : Kurva Daerah Penerimaan dan Penolakan UjiF

Uji t berfungsi untuk mengetahui apakah setiap variabel online reservations dan offline reservations berpengaruh terhadap tingkat hunian kamar.

1) Pengaruh Online Reservations Terhadap Tingkat Hunian Kamar di The Jayakarta Yogyakarta Hotel and Spa

Untuk mengetahui pengaruh yang nyata dari online reservations terhadap tingkat hunian kamar maka dapat diuji dengan menggunakan distribusi t. Pengujian menggunakan tingkat signifikansi 0,05/2 =0,025 dengan 2 sisi (Purnomo:157):

Perumusan hipotesis : 
$\mathrm{H}_{\mathrm{o}} ; \mathrm{b}=0$ (tidak ada pengaruh antara variabel $\mathrm{X} 1$ terhadap variabel $\mathrm{Y}$ )

$\mathrm{H}_{\mathrm{o}} ; \mathrm{b}>0$ (adanya pengaruh antara variabel $\mathrm{X} 1$ terhadap variabel $\mathrm{Y}$ )

Kriteria Uji :

Rumus tabel :

Df $=$ jumlah sampel $(\mathrm{n})-2=36-2=34$

$t_{\text {tabel }}=2,032$

a. Berdasarkan nilai Signifikansi

1) Jika nilai Signifikansi $>0,05$ maka online reservtaions tidak berpengaruh terhadap tingkat hunian kamar.

2) Jika nilai Signifikansi $<0,05$ maka online reservations berpengaruh terh adap tingkat hunian kamar.

b. Berdasarkan perbandingan $t_{\text {tabel }}$ dan $t_{\text {hitung }}$

1) Apabila $t_{\text {hitung }}>t_{\text {tabel, }}$ maka $H_{o}$ ditolak, yang berarti adany a pengaruh yang signifikan antara online reservations terhadap tingkat hunian kamar

2) Apabila $t_{\text {hitung }}<t_{\text {tabel, }}$ maka $H_{o}$ diterima, yang berarti tidak ada pengaruh antara online reservations terhadap tingkat hunian kamar

Tabel 14. Hasil Uji T Online Reservations

\begin{tabular}{|c|c|c|c|c|c|c|}
\hline \multicolumn{7}{|c|}{ Coefficients $^{\mathbf{a}}$} \\
\hline & \multirow[t]{2}{*}{ Model } & \multicolumn{2}{|c|}{ Unsta ndardized Coefficients } & $\begin{array}{c}\text { Standardized } \\
\text { Coefficients }\end{array}$ & \multirow[t]{2}{*}{$\mathrm{T}$} & \multirow[t]{2}{*}{ Sig. } \\
\hline & & B & Std. Error & Beta & & \\
\hline \multirow[b]{2}{*}{1} & (Constant) & $-3.915 \mathrm{E}-16$ & .083 & & .000 & 1.000 \\
\hline & $\begin{array}{l}\text { Zscore: Online } \\
\text { Reservation }\end{array}$ & .870 & .085 & .870 & 10.272 & .000 \\
\hline
\end{tabular}

a. Dependent Variable: Zscore: TingkatHunian Kamar

Sumber: Da ta Primer yang Diolah (2020)

Nilai signifikansi menunjukkan sebesar 0,000 maka $0,000<0,05$. Hal ini dapat diartikan bahwa online reservations berpen garuh secara signifikan terhadap tingkat hunian kamar.

Hasil uji $\mathrm{t}$ online reservations diatas dapat dilihat bahwa $t_{\text {hitung }}$ diperoleh sebesar 10,272 maka dapat menarik kriteria $t_{\text {hitung }}(10,272)>t_{\text {tabel }}(2,032)$ yang berarti adanya pengaruh yang signifikan antara online reservations terhadap tingkat hunian kamar di The Jayakarta Yogyakarta Hotel and Spa. Penentuan kurva penerimaan Ho dan penolakan Ha dapat dilihat pada Gambar 2 dibawah.

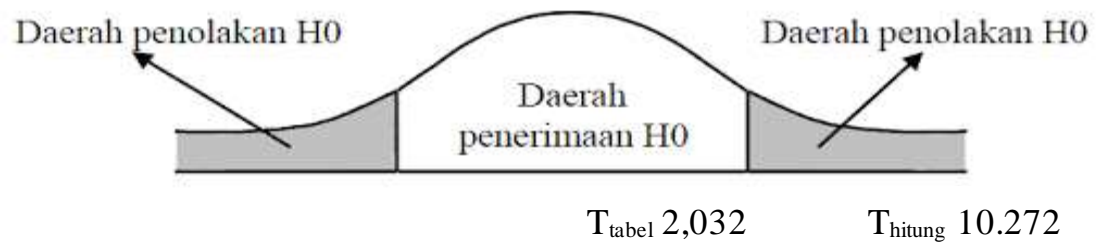

Gambar 2 : Kurva Daerah Penerimaan Hodan Penolakan Ha Online Reservations Dengan Ujit

2) Pengaruh Offline Reservations Terhadap Tingkat Hunian Kamar di The Jayakarta Yogyakarta Hotel and Spa

Untuk mengetahui pengaruh yang nyata dari offline reservations terhadap tingkat hunian kamar maka dapat diuji dengan menggunakan distribusi t. Pengujian menggunakan tingkat signifikansi $0,05 / 2=0,025$ dengan 2 sisi (Purnomo:157):

Perumusan hipotesis :

$\mathrm{H}_{\mathrm{o}} ; \mathrm{b}=0$ (tidak ada pengaruh antara variabel $\mathrm{X} 2$ terhadap variabel $\mathrm{Y}$ )

$\mathrm{H}_{\mathrm{o}} ; \mathrm{b}>0$ (adanya pengaruh antara variabel $\mathrm{X} 2$ terhadap variabel $\mathrm{Y}$ )

Rumus Ttabel :

Kriteria Uji : 
Df $=$ jumlah sampel (n) $-2=36-2=34$

$\mathrm{T}$ tabel $=2,032$

a. Berdasarkan nilai Signifikansi

1) Jika nilai Signifikansi > 0,05 maka offline reservtaions tidak berpengaruh terhadap tingkat hunian kamar.

2) Jika nilai Signifikansi $<0,05$ maka offline reservations berpengaruh terh a dap tingkat hunian kamar.

b. Berdasarkan perbandingan $t_{\text {tabel }}$ dan $t_{\text {hitung }}$

1) Apabila $t_{\text {hitung }}>t_{\text {tabel, }}$ maka $H_{o}$ ditolak, yang berarti adanya pengaruh yang signifikan antara offline reservations terhadap tingkat hunian kamar

2) Apabila $t_{\text {hitung }}<t_{\text {tabel, }}$ maka $H_{o}$ diterima, yang berarti tidak ada pengaruh antara offline reservations terhadap tingkat hunian kamar

Tabel 15. Hasil Uji T Offline Reservations

\begin{tabular}{|c|c|c|c|c|c|c|}
\hline \multicolumn{7}{|c|}{ Coefficients $^{a}$} \\
\hline & \multirow[t]{2}{*}{ Model } & \multicolumn{2}{|c|}{ Unsta ndardized Coefficients } & $\begin{array}{l}\text { Standardized } \\
\text { Coefficients }\end{array}$ & \multirow[t]{2}{*}{$\mathrm{T}$} & \multirow[t]{2}{*}{ Sig. } \\
\hline & & B & Std. Error & Beta & & \\
\hline \multirow[b]{2}{*}{1} & (Constant) & $9.888 \mathrm{E}-17$ & .063 & & .000 & 1.000 \\
\hline & $\begin{array}{l}\text { Zscore: Offline } \\
\text { Reservation }\end{array}$ & .928 & .064 & .928 & 14.563 & .000 \\
\hline
\end{tabular}

a. Dependent Variable: Zscore: Tingkat Hunian Kamar

Sumber: Da ta Primer yang Diolah, 2020

Nilai signifikansi (Sig.) menunjukkan sebesar 0,000, maka $0,000<0,05$. Hal ini dapat diartikan bahwa variabel offline reservations berpengaruh secara signifikan terhadap tingkat hunian kamar.

Berdasarkan hasil uji $\mathrm{t}$ offline reservations diatas pada dilihat bahwa $\mathrm{t}_{\text {hitung }}$ diperoleh sebesar 14.563 maka dapat menarik kriteria $t_{\text {hitung }}(14.563)>t_{\text {tabel }}(2,032)$ y ang berarti adanya pengaruh yang signifikan antara offline reservations terhadap tingkat hunian kamar di The Jayakarta Yogyakarta Hotel and Spa. Berikut merupakan kurva penerim aan Ho dan penolakan Ho dapat dilihat pada Gambar 3. dibawah

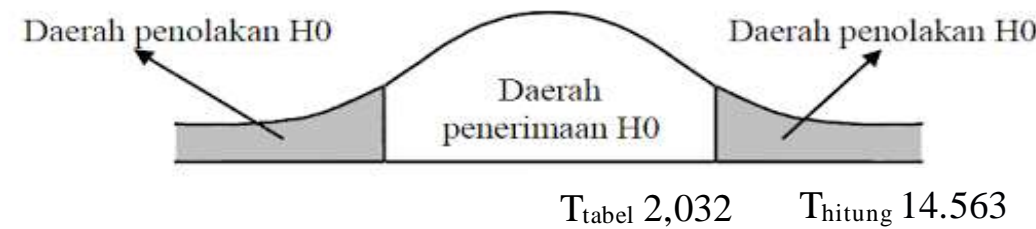

Gambar 3 : Kurva Daerah Penerimaan Hodan Penolakan Ho Offline Reservations Dengan Ujit

5. Koefisien Determinasi

Untuk mengetahui sumbangan secara simultan variabel online reservations dan offline reservations terhadap tingkat hunian kamar yaitu dengan melihat pada $\mathrm{R}$ square $\left(\mathrm{R}^{2}\right)$ yaitu menunjukkan koefisien determinasi (Purnomo :154).

Tabel 16. Koefisien Determinasi

\begin{tabular}{cccccc}
\hline \multicolumn{6}{c}{ Model Summary $^{\mathbf{b}}$} \\
\hline Model & $\mathrm{R}$ & R Square & $\begin{array}{c}\text { Adjusted } \\
\text { Square }\end{array}$ & $\begin{array}{c}\text { Std. Error of the } \\
\text { Estimate }\end{array}$ & Durbin-Watson \\
\hline 1 & $.997^{\mathrm{a}}$ & .995 & .995 & .07379793 & 2.531 \\
\hline
\end{tabular}

a. Predictors: (Constant), Zscore: Offline Reservation,Zscore: Online Reservation

b. Dependent Variable:Zscore: Tingkat Hunian Kamar 
Sumber: Da ta Primeryang Diolah (2020)

Pada tabel diatas menunjukan nilai Rsquare sebesar 0,995. Angka ini dikali 100 persen, yang artinya 99,5 persen presentase sumbangan pengaruh antara online reservations dan offline reservations terhadap tingkat hunian kamar, sedangkan sisanya 0,5 persen dipengaruhi oleh variabel lain.

3.3 Variabel yang Dominan Mempengaruhi Tingkat Hunian Kamar di The Jayakarta Yogyakarta Hotel and Spa

Untuk mengetahui variabel yang dominan memepengaruhi tingkat hunian kamar di The Jayakarta Yogyakarta Hotel and Spa yaitu sebagai berikut

\section{Koefisien Determinasi Online Reservations}

Tabel 17. Nilai Determinasi Online Reservations

\begin{tabular}{ccccc}
\hline \multicolumn{5}{c}{ Model Summary } \\
\hline Model & $\mathrm{R}$ & R Square & Adjusted R Square & Std. Error of the Estimate \\
1 & $.870^{\mathrm{a}}$ & .756 & .749 & .50086539 \\
\hline
\end{tabular}

a. Predictors: (Constant), Zscore: Online Reservation

b. Dependent Variable:Zscore: TingkatHunian Kamar

Sumber: Da ta Primer yang Diolah (2020)

Nilai determinasi online reservations diperoleh Rsquare $=0,756$. Hal ini memiliki arti bahwa sebesar 75,6 persen tingkat hunian kamar dipengaruhi oleh online reservations dan sebesar 24,4 persen sisanya dipengaruhi oleh variabel lain .

1. Koefisien Determinasi Offline Reservations

Tabel 18. Nilai Determinasi Offline reservations

\begin{tabular}{ccccc}
\hline \multicolumn{5}{c}{ Model Summary } \\
\hline Model & $\mathrm{R}$ & R Square & Adjusted R Square & Std. Error of the Estimate \\
1 & $.928^{\mathrm{a}}$ & .862 & .858 & .37712228 \\
\hline
\end{tabular}

a. Predictors: (Constant), Zscore: Offline Reservation

b. Dependent Variable:Zscore: Tingkat Hunian Kamar

Sumber: Da ta Primer yang Diolah (2020)

Dapat dilihat bahwa nilai determinasi offline reservations $\mathrm{Rsquare}=0,862$. Hal ini berarti sebesar 86,2 persen tingkat hunian kamar dipengaruhi oleh offline reservations dan sebesar 13,8 persen sisanya dipengaruhi oleh variabel lain. Pada Tabel 4.17 Nilai determinasi offline reservations di atas dapat dilihat bahwa nilai determinasi Rsquare $=0,862$. Hal ini berarti sebesar 86,2 persen tingkat hunian kamar dipengaruhi oleh offline reservations dan sebesar 13,8 persen sisanya dipengaruhi oleh variabel lain.

Dari hasil tersebut dapat dijelaskan melalui tabel dibawah ini mengenai variabel offline reservations yang lebih dominan dibandingkan online reservations.

Tabel 19. Sumber Pemesanan Offline Reservations di The Jayakarta Yogyakarta Hotel a nd Spa padatahun 2017-2019

\begin{tabular}{cccccccc}
\hline \multirow{2}{*}{ Sumber Pemesanan } & \multicolumn{2}{c}{$\mathbf{2 0 1 7}$} & \multicolumn{2}{c}{$\mathbf{2 0 1 8}$} & \multicolumn{2}{c}{$\mathbf{2 0 1 9}$} & \multirow{2}{*}{ Rata-rata } \\
\cline { 2 - 7 } & RNO & \% & RNO & \% & RNO & \% & \\
\hline Individual/Walk in & 4.282 & 9,09 & 3.811 & 9,09 & 6958 & 15,11 & 11,1 \\
Travel agent FIT & 754 & 1,60 & 1.282 & 1,60 & 1686 & 3,66 & 2,28 \\
Travelagent GIT & 2.672 & 5,67 & 1.729 & 5,67 & 6742 & 14,64 & 8,66 \\
Corporate & 6.547 & 13,90 & 7.762 & 13,90 & 11987 & 26,03 & 17,94 \\
Government & 3.995 & 8,48 & 1.585 & 8,48 & 3413 & 7,41 & 8,12 \\
Airline & 124 & 0,26 & 61 & 0,26 & 631 & 1,37 & 0,63 \\
\hline
\end{tabular}

Sumber: Da ta Front Office The Jayakarta Yogyakarta (2020)

Pada tabel di atas dapat diketahui bahwa pada variabel offline reservations, sumber pemesanan yang lebih dominan dari Coperate setiap tahunnya. Sumber pemesanan 
coperate sendiri rata-rata yang dapat diketahui dari tahun 2017 sampai 2019 yaitu 17,94 persen. Hal ini dikarenakan banyaknya kerjasama dengan perusahaan-perusaha an daerah maupun antardaerah. Perusahaan yang bekerjasama dengan Hotel The Jayakarta Yogyakarta biasanya melakukan pemesanan kamar dengan paket event yang akan mereka selenggarakan di hotel tersebut. Seperti event untuk seminar, meeting, acara ulang tahun perusahaan maupun penyambutan atau pesta perusahaan lainnya yang menjadikan The Jayakarta Yogyakarta sebagai venue untuk acara tersebut. Salah satu perusahaan daerah Yogyakarta yang sering memakai jasa mereka yaitu PT Kusuma Sendang Mekarjaya sebagai tempat untuk melakukan ulang tahun perusahan.

\subsection{Upaya yang Dilakukan Untuk Meningkatkan Tingkat Hunian Kamar}

Banyak hal yang dilakukan hotel untuk meningkatkan tingkat hunian kamar, berbagai sumber-sumber pemesanan dikerahkan untuk meningkatkan tingkat hunian kamar tersebut. Di The Jayakarta Yogyakarta Hotel and spa sumber pemesanan kamar dibagi menjadi online reservations dan offline reservations. Dari data penelitian yang telah dipaparkan di atas menunjukkan variabel online reservations di The Jayakarta Yogykarta Hotel and Spa memiliki pengaruh yang lebih sedikit dibandingkan variabel offline reservations dalam meningkatkan tingkat hunian kamar. Oleh karena itu diperlukan upaya dalam meningkatkan variabel yang tidak dominan tersebut. Sebelum mengetahui upaya apa saja yang dilakukan, berikut merupakan kendala-kendala penjulan online dan offline reservations di The Jayakarta Yogyakarta Hotel and Spa.

1. Kendala-Kendala Penjualan Online Dan Offline Reservation di The Jayakarta Yogyakarta Hotel and spa

Dalam menangani pemesanan atau reservations di hotel tentu memiliki kendala meningkatkan penjualan kamar. Berikut merupakan kendala kendala yang dialami The Jayakarta Yogyakarta Hotel and spa pada online, offline reservations dalam meningkatkan penjualan kamar.

1) Kendala dalam Online reservations

Berikut adalah kendala penjualan kamar melalui online reservations.

a. Online contact person tamu tidak tercantum di voucher tamu, sehingga mempersulit pihak hotel mengenai detail kebutuhan tamu.

b. Harga dalam online travel agent lebih murah jika dibandingkan harga di hotel, sehingga jika tamu ingin extent memperpanjang dengan harga asli dari hotel.

c. Diskon atau promo dalam online travel agent mempengaruhi jumlah revenue yang akan diperoleh pihak hotel, karena harga reservations sudah termasuk diskon.

2) Kendala dalam Offline Reservations

Berikut adalah kendala penjualan kamar melalui offline reservations.

a. Menurunkan harga pasar untuk menarik minat travel agent untuk bekerja sama.

b. Memberikan complimentary kepada travel agent untuk mendapatkan banyak klien.

c. Reservasi yang belum memberikan deposit tetapi klien sulit dihubungi

d. Kendala dalam meminta uang pelunasan kepada klien.

e. Menyamaratakan harga untuk setiap tipe kamar untuk group besar yang memesan kamar.

f. Menjalin hubungan dengan klien travel agent maupun yang berkepentingan agar kerjasama tetap terjalin dengan kesepakatan yang baik .

3) Kendala Dalam Meningkatkan Tingkat Hunian Kamar

Berikut adalah kendala dalam meningkatkan tingkat hunian kamar di The Jayakarta Yogyakarta Hotel and spa 
a. Persaingan harga untuk mendapatkan tamu.

b. Banyaknya hotel disekitar The Jayakarta Yogyakarta mempengaruhi banyaknya pilihan hotel untuk dipilih tamu.

c. Letak hotel yang jauh dari pusat kota.

d. Bangunan hotel yang terlihat tua mempengaruhi tamu yang ingin menginap.

\section{Upaya yang Dilakukan Untuk Meningkatkan Variabel Online Reservations}

Dapat kita lihat di atas bahwa hasil yang ditunjukkan oleh data tentang Variabel yang Dominan Mempengaruhi Tingkat Hunian Kamar di The Jayakarta Yogyakarta Hotel and spa yaitu Variabel $\mathrm{X}_{2}$ atau variabel Offline Reservations terhadap tingkat hunian kamar di The Jayakarta Yogyakarta. Hasil tersebut menjelaskan bahwa pada uji koefisien determinasi didapat 86,2 persen tingkat hunian kamar dipengaruhi oleh offline reservations dibandingkan nilai determinasi pada online reservations sebesar 75,6 persen.. Dalam hal ini variabel lain yang tidak dominan terhadap tingkat hunian kamar yaitu variabel $\mathrm{X}_{1}$ atau online reservations terhadap tingkat hunian kamar.

Berikut merupakan online travel agent yang bekerjasama dengan Hotel The Jayakarta Yogyakarta Hotel and Spa :

Tabel20. Online Travelagent Yang Bekerjasama Dengan Hotel The Ja yakarta Yogyakarta Hotel and Spa

\begin{tabular}{|c|c|c|c|c|c|c|c|}
\hline & \multirow{2}{*}{ Segment } & \multicolumn{2}{|c|}{2017} & \multicolumn{2}{|c|}{2018} & \multicolumn{2}{|c|}{2019} \\
\hline & & RNO & $\%$ & RNO & $\%$ & RNO & $\%$ \\
\hline \multirow{13}{*}{ Online } & Traveloka.com & 3.262 & 6,93 & 5.091 & 10,78 & 4.534 & 9,84 \\
\hline & $\begin{array}{c}\text { Agoda Company } \\
\text { Pte.Ltd. }\end{array}$ & 823 & 1,75 & 482 & 1,02 & 731 & 1,59 \\
\hline & Booking.Com & 273 & 0,58 & 223 & 0,47 & 296 & 0,64 \\
\hline & Pegipegi.Com & 270 & 0,57 & 78 & 0,17 & 216 & 0,47 \\
\hline & Tiket.Com & 193 & 0,41 & 423 & 0,90 & 178 & 0,39 \\
\hline & Fastbooking & 155 & 0,33 & 27 & 0,06 & 131 & 0,28 \\
\hline & Expedia $\mathrm{Tt}$ & 72 & 0,15 & 177 & 0,37 & 81 & 0,18 \\
\hline & Trip .Com & 0 & 0,00 & 5 & 0,01 & 11 & 0,02 \\
\hline & Hotelstravel & 4 & 0,01 & 1 & 0,002 & 8 & 0,02 \\
\hline & Klikhotel.Com & 10 & 0,01 & 2 & 0,004 & 0 & 0,00 \\
\hline & Hotels.com & 3 & 0,02 & 2 & 0,004 & 2 & 0,004 \\
\hline & Priceline.com & 0 & 0 & 0 & 0 & 1 & 0,002 \\
\hline & Fave.com & 0 & 0 & 1 & 0,002 & 0 & 0 \\
\hline \multicolumn{2}{|r|}{ Total } & 24.881 & 52,84 & 23.667 & 50,26 & 22.952 & 49,84 \\
\hline
\end{tabular}

Sumber: Da ta Front Office The Ja yakarta Yogy akarta, 2020

Beberapa hal yang menyebabkan online reservations tidak dominan yaitu

1. Pihak hotel telah bekerjasama dengan pemerintah ataupun perusahaan untuk mengadakan event atau acara pemerintahan atau perusahaan di hotel. Seperti acara seminar, workshop, penataran.

2. Hanya tamu personal website dan tamu online travel agent yang memakai jasa online reservastions. Rombongan pemerintah, perusahaan, travel agent, walk-in guest semua melalui offline reservations. 
3. Tamu bergroup lebih mendominasi memakai Offline reservasi dikarenakan kebanyakan rombongan tour travel agent atau rombongan government dan cooperate

4. Letak hotel yang tidak di pusat kota menyebabkan tidak banyak orang memilih menggunakannya untuk urusan traveling dan memesan melalui online travel agent yang ada.

Oleh karena itu untuk lebih meningkatkan variabel X1 terhadap Y atau online reservations terhadap tingkat hunian kamar yaitu dilakukan beberapa upaya yang dilakukan hotel. Beberapa upaya untuk meningkatkan online reservations yang telah dilakukan hotel yaitu :

1. Mengikuti seminar yang diadakan oleh komunitas-kominitas E-commerce

2. Belajar untuk mengetahui bisnis online

3. Seminar tentang membangun brand community untuk mengembangkan brand awareness mereka di media sosial sehingga membuat orang mau mengikuti media sosial mereka.

4. Mengikuti seminar dari praktisi online travel agent

5. Seminar tentang bisnis dan tour travel revolutions

6. Mengetahui cara kerja online travel agent

7. Upaya untuk mengetahui cara membuat surat perjanjian maupun kontrak dengan online travel agent

8. Mengalokasikan lebih banyak anggaran pemasaran saat "high season" dengan menawarkan diskon menginap, di The Jayakarta Yogyakarta mengalami high season saat desember atau akir bulan.

9. Sales and marketing melakukan lebih banyak promosi untuk meningkatkan penjualan kamar dengan merawarkan diskon menginap ataupun diskon di restaurant yang ada di The Jayakarta Yogyakarta Hotel and Spa.

Mengetahui tren promosi terkini dengan cara mengupdate informasi seputar informasi sekarang untuk dijadikan promosi yang menarik bagi hotel, seperti hari ibu dengan memberikan promosi diskon menginap bagi anak yang berkunjung dengan sang ibu.

1. Menyederhanakan situs web hotel, sehingga pelanggan lebih mudah mengakses website resmi hotel dalam melakukan pemesanan kamar. Situs resmi hotel yaitu www.jayakartahotelsresorts.com dan www.yogyakarta.jayakartahotelsresorts.com

a. Dengan mengikuti komunitas e-commerce tentang cara membuat website yang menarik dan mudah diakses.

b. Mengikuti seminar Group Jayakarta tentang pengembangan website hotel.

2. Memperbanyak promosi dan voucer benefit bagi membership The Jayakarta Group, baik bagi membership Jayakarta Premium Gold ataupun Jayakarta Premium Platinum sehingga menigkatkan loyalitas mereka dalam memakai akomodasi The Jayakarta Group. 
a. Memberikan promosi bagi keanggotaan member jika untuk member Jayakarta Premium Gold dengan target poin tertentu akan mendapatkan bebas menginap di Akomodasi Jayakarta Group manapun selama ketentuan banyaknya poin yang terkumpul.

b. Dengan keanggotaan Premium Platinum akan mendapatkan benefit yang lebih banyak dari keanggotaan Premium Gold.

3. Memperbanyak promosi saat hari hari besar saat hari-hari besar akan berlangsung seperti menjelang hari raya lebaran, hari raya idul adha, memperingati hari kemerdekaan 17 Agustus. The Jayakarta Yogyakarta memperbanyak iklan atau promosi dalam menyambut hari-hari libur nasional tersebut sehingga masyarakat berminat untuk menginap atau memakai akomodasi The Jayakarta Yogyakarta.

a. Memberikan paket diskon menginap saat hari hari besar seperti 17 Agustus akan ada diskon menginap 20 persen.

4. Memperhatikan review hotel, hal ini dilakukan dengan aktif pada online travel agent hotel.

a. Membalas komen-komen review dari tamu atau masyarakat yang ingin mengetahui info hotel, dalam hal ini hotel banyak melakukan di Tripadvisor.com sebagai acuan masyarakat dalam memilih hotel. Semakin banyak review bagus hotel maka hotel tersebut menjadi rekomendasi masyarakat luas dalam memilih tempat akomodasi dan menjadi akomodasi populer pilihan.

b. Memperhatikan review buruk hotel untuk ditelaah dan dievaluasi

5. Aktif dalam memberikan informasi terbaru hotel melalui sosial media termasuk promosi terbaru yang dimiliki hotel. Sosial media yang dimiliki hotel yaitu (instagram, facebook, dan twitter)

a. Seperti memberikan informasi jika ingin memesan tempat untuk olahraga paintball dengan reservasi ke nomor tujuan.

b. Mengupdate aktifitas yang sedang dilakukan serperti adanya Japanese student yang belajar budaya di The Jayakarta Yogyakarta Hotel.

6. Mengetahui strategi market saat terbaru

a. Banyak tamu yang hari dari luar negeri yang banyak meminta request dijemput di bandara, maka untuk memudahkan mereka pihak hotel membuat package room dengan airport pick up. Hal ini untuk memudahkan mereka sampai ke hotel tanpa menelpon atau mengabari pihak hotel untuk menjemput dibandara.

b. Mahasiswa ataupun masyarakat asing yang berkunjung di jogja dapat belajar memainkan gamelan di The Jayakarta Yogyakarta Hotel and Spa.

7. Upaya Yang Dilakukan Untuk Meningkatkan Pemesanan Melalui Online Travel agent yang Rendah

Berdasarkan pada Tabel 4.19 di atas dapat dilihat bahwa Online Travel agent yang memiliki tiga urutan terendah dalam melalukan pemesanan ke hotel The Jayakarta Yogyakarta 
yaitu Hotels.com, Priceline.com, dan Fave.com. dari ketiga ini fave.com tidak tidak memiliki kontrak lagi dengan the Jayakarta Yogyakarta dikarenakan sedikitnya masyarakat yang menggunakan online travel agent fave.com untuk membooking The Jayakarta Yogyakarta Hotel and Spa sebagai pilihan akomodasi.

Dalam hal ini untuk meningkatkan tingkat pemesanan hotel melalui online travel agent tersebut, pihak hotel memiliki beberapa cara yaitu :

1. Memperbarui kontrak yang ada dengan online travel agent tersebut terkait dengan rate, benefit, dan kebijakan yang ada.

a. Jika masa kontrak telah habis dan hotel ingin melanjutkan kerjasama maka perlu adanya kontrak baru dengan perjanjian antara hotel dan online travel agent yang baru.

Memeriksa review hotel melalui online travel agent tersebut, terkait dengan hotel, apakah hotel memiliki review baik ataupun buruk. Karena review berpengaruh bagi masyarakat dalam memilih tempat akomodasi.

a. Jika review buruk maka hotel akan membalas review dengan meminta maaf dan melakukan evaluasi terhadap review tersebut.

3. Memeriksa rate hotel serta benefit yang didapatkan,

a. Hotel akan menghubungi online travel agent tersebut jika rate rendah agar online travel agent tersebut tidak mematikan pasaran harga hotel. Tetapi jika tingginya harga hotel di online travel agent tersebut hotel juga akan menghubungi online travel agent tersebut agar tidak menimbulkan review buruk terkait perbandingan harga, fasilitas dan pelayanan yang disediakan.

4. Memastikan rate perjanjian dengan rate yang diterima hotel sesuai untuk menghindari "online travel agent curang" karena mengirimi rate dibawah nilai perjanjian, hal ini bisa menyebabkan pemutusan kontrak dengan online travel agent tersebut.

Pihak hotel tidak bisa menyalahkan online travel agent tersebut dikarenakan persaingan online travel agent yang banyak menyebabkan masyarakat memakai online travel agent yang paling terkenal atau terpopuler untuk memudahkan mereka memilih akomodasi pilihan.

\section{KESIMPULAN}

Berdasarkan penelitian tentang online dan offline reservations terhadap tingkat hunian kamar di The Jayakarta Yogyakarta Hotel and Spa dapat disimpulkan yaitu

1. Secara simultan terdapat pengaruh yang positif dan signifikan antara online reservations dan offline reservations terhadap tingkat hunian kamar di The Jayakarta Yogyakarta Hotel and spa. Dapat diketahui melalui beberapa uji analisis yang telah dilakukan. Dari analisis korelasi berganda menunjukkan $\mathrm{R}=0.997$ berarti bahwa hubungan antara online reservations dan offline reservations terhadap tingkat hunian kamar memiliki hubungan yang sangat kuat. Pada uji analisis regresi berganda menunjukan nilai Sig. sebesar $0,000<0,05$ maka variabel online reservations dan offline reservations berpengaruh signifikan terhadap tingkat hunian kamar. Pada uji $\mathrm{F}$, nilai $\mathrm{F}_{\text {hitung }}(3196,788)>\mathrm{F}_{\text {tabel }}(3,28)$ berarti antara online reservations dan offline reservations secara bersama-sama atau simultan berpengaruh secara nyata dan signifikan terhadap tingkat hunian kamar. Pada uji t online reservations $t_{\text {hitung }}(10,272)>t_{\text {tabel }}(2,032)$, uji $\mathrm{t}$ offline reservations $\mathrm{t}_{\text {hitung }}(14.563)>\mathrm{t}_{\text {tabel }}(2,032)$ artinya adanya pengaruh yang signifikan antara online dan offline reservations terhadap tingkat hunian kamar. Pada uji koefisien determinasi 99,5 persen presentase sumbangan pengaruh antara online reservations dan offline reservations terhadap tingkat hunian kamar, sedangkan sisanya 0,5 persen dipengaruhi oleh variabel lain.

2. Variabel yang lebih dominan mempengaruhi tingkat hunian kamar di The Jayakarta Yogyakarta Hotel and spa adalah variabel offline reservations. Dari uji determinasi dengan hasil yang didapatkan sebesar 75,6 persen tingkat hunian kamar dipengaruhi oleh online reservations dan sebesar 24,4 persen sisanya dipengaruhi oleh variabel lain Serta sebesar 86,2 persen tingkat hunian kamar dipengaruhi oleh offline reservations dan sebesar 13,8 persen sisanya dipengaruhi oleh variabel lain. 
3. Upaya yang dilakukan untuk meningkatkan variabel yang tidak dominan yaitu dengan mengikuti seminar yang diadakan oleh komunitas-kominitas E-commerce dan online travel agent, memperhatikan review masyarakat, memberikan informasi terbaru kepada masyarakat terkait dengan informasi hotel maupun promosi yang diadakan, memberikan promosi kepada masyarakat melalui online travel agent maupun dari website resmi hotel. Serta menyederhanakan website resmi hotel untuk memudahkan masyarakat dalam membaca informasi ataupun membuat reservasi.

Adapun saran yang dapat diberikan oleh penulis yaitu diharapkan pihak hotel agar dapat menjalin dan menjaga hubungan yang baik dengan pihak-pihak sumber-sumber reservasi agar dapat memaksimalkan tingkat hunian kamar di The Jayakarta Yogyakarta Hotel and Spa. Dalam online reservations diharapkan pihak hotel menulis data tamu dengan lengkap agar memudahkan dalam meninjau ulang tamu. Diharapkan pihak hotel meningkatkan dalam mempromosikan hotel terkhusus dalam hal online sehingga diera modern dan digital sekarang ini, online reservations dapat lebih meningkatkan tingkat hunian kamar secara maksimal. Pihak hotel diharapkan dapat merekontruksi atau memperbarui beberapa bagian hotel agar terlihat lebih modern dan baru sehingga tamu yang menginap merasa lebih nyaman.

\section{Ucapan terima kasih}

Puji dan Syukur kehadirat Tuhan Yang Maha Esa atas berkat dan rahmat-Nya sehingga penulis dapat menyelesaikan jurnal yang berjudul "Pengaruh Online dan Offline Reservations Terhadap Tingkat Hunian Kamar The Jayakarta Yogyakarta Hotel" ini. Jurnal ini terwujud berkat dukungan, bantuan, bimbingan, serta masukan dari beberapa pihak. Untuk itu, penulis mengucapkan terima kasih kepada Bapak Dr. Drs. I Nyoman Sunarta, M.Si. selaku Dekan Fakultas Pariwisata Universitas Udayana. Ibu Dra. Anak Agung Putri Sri, M.Si. Selaku Koordinator Program Studi Diploma IV Pariwisata Fakultas Pariwisata, Universitas Udayana. Serta selaku pembimbing akademik, yang telah memberikan saran dan masukan bagi Laporan Tugas Akhir ini agar semakin sempurna. Ibu Dr. Ni Putu Ratna Sari, S.ST.Par.,M.Par, dan Ibu Agung Sri Sulistyawati, SST. Par, M.Par selaku Dosen Pembimbing Laporan Tugas Akhir ini. Ibu Putu Diah Kesuma Dewi, S.ST.Par.,M.Par dan Bapak Putu Agus Wikanatha Sagita,ST.Par.,M.Par selaku Tim Penguji Laporan Tugas Akhir ini. Seluruh dosen Fakultas Pariwisata Universitas Udayana yang tidak dapat penulis sebutkan satu-satu, yang telah mendidik dan memberikan ilmunya kepada penulis. Segenap Tata Usaha Fakultas Pariwisata Universitas Udayana. Pihak The Jayakarta Yogyakarta Hotel and Spa yang telah bersedia memberikan data dan mengizinkan untuk melakukan penelitian. Keluarga tercinta Mama (Sholikatun), Bapak (R. Joko Suhary ono), Kakak (Rr. Melanza Agata Helikano) dan Adik (R. Oddie Sabina Herlikano) dan seluruh anggota keluarga besar Siswosumarto yang telah memberikan dukungan, motivasi serta doanya kepada penulis. Sahabat-sahabat penulis di Jogja maupun di Bali yang selalu memberikan support dan doa. Temanteman seperjuangan Diploma IV Pariwisata, Fakultas Pariwisata, Universitas Udayana angkatan 2015.

\section{DAFTAR PUSTAKA}

Agus, Sulastiyono. 2008. Seri Manajemen Usaha Jasa Sarana Pariwisata Dan. Akomodasi; Teknik Dan Prosedur Divisi Kamar. Bandung: Penerbit Alfabeta CV

Febriantara, Satria. 2012. Pengaruh Online Dan Offline reservations Terhadap Tingkat Hunian

Kamar Hotel All Seasons Di Legian-Bali. Skripsi. Universitas Udayana.

Purnomo, Rochmat Aldy. 2016. Analisis Statistik Ekonomi dan Bisnis Dengan SPSS. Ponorogo :

CV Wage Group.

Santoso, Singgih. 2008. Panduan Lengkap Menguasai SPSS. Jakarta : PT Alex Media Konputindo.

Sulastiyono, A. 2011. Seri Manajemen Usaha Jasa Sarana Pariwisata Dan Akomodasi:

Manajemen Penyelenggaraan Hotel. Bandung: Penerbit Alfabeta.

Supranto. J. 1997. Pengukuran Tingkat Kepuasan Pelanggan. Jakarta: Rineka ipta. 